\title{
Molecular and pathological signatures of epithelial-mesenchymal transitions at the cancer invasion front
}

\author{
Olivier De Wever · Patrick Pauwels $\cdot$ Bram De Craene \\ Michèle Sabbah · Shahin Emami · Gérard Redeuilh • \\ Christian Gespach · Marc Bracke · Geert Berx
}

Accepted: 12 June 2008 / Published online: 22 July 2008

(C) Springer-Verlag 2008

\begin{abstract}
Reduction of epithelial cell-cell adhesion via the transcriptional repression of cadherins in combination with the acquisition of mesenchymal properties are key determinants of epithelial-mesenchymal transition (EMT). EMT is associated with early stages of carcinogenesis, cancer invasion and recurrence. Furthermore, the tumor stroma dictates EMT through intensive bidirectional communication. The pathological analysis of EMT signatures is critically, especially to determine the presence of cancer cells at the resection margins of a tumor. When diffusion barriers
\end{abstract}

\footnotetext{
O. De Wever $(\varangle) \cdot$ M. Bracke

Laboratory of Experimental Cancer Research,

Department of Radiotherapy and Nuclear Medicine,

Ghent University Hospital, De Pintelaan 185,

9000 Ghent, Belgium

e-mail: olivier.dewever@UGent.be

P. Pauwels

Department of Pathology, Ghent University Hospital,

9000 Ghent, Belgium

B. De Craene · G. Berx $(\square)$

Molecular and Cellular Oncology Unit,

Department for Molecular Biomedical Research, VIB,

Technologiepark 927, Zwijnaarde, 9052 Ghent, Belgium

e-mail: geert.berx@dmbr.ugent.be

B. De Craene · G. Berx

Department of Molecular Biology, Ghent University,

9052 Ghent, Belgium

M. Sabbah · S. Emami · G. Redeuilh · C. Gespach

INSERM U 673, Paris, France

C. Gespach

Laboratory of Molecular and Clinical Oncology of Solid Tumors, Faculté de Médecine, Université Pierre et Marie Curie-Paris 6,

755071 Paris Cedex 12, France
}

disappear, EMT markers may be detected in sera from cancer patients. The detection of EMT signatures is not only important for diagnosis but can also be exploited to enhance classical chemotherapy treatments. In conclusion, further detailed understanding of the contextual cues and molecular mediators that control EMT will be required in order to develop diagnostic tools and small molecule inhibitors with potential clinical implications.

Keywords Stroma $\cdot$ Cadherin $\cdot$ EMT $\cdot$ Metastasis . Therapy

\section{Introduction}

Epithelial-mesenchymal transition (EMT) is a type of plasticity during which epithelial cells lose many of their epithelial characteristics and acquire properties that are typical of mesenchymal cells. Multiple terms, including epithelialmesenchymal transformation and transdifferentiation have been used to refer to EMT. To understand this, it is important to review the terms epithelium and mesenchyme. An epithelium is a sheet of cells that adhere laterally to each other by cell-to-cell junctions. The epithelial layer is polarized in such a way that bottom and top can be defined as basal and apical (inside and outside). The filamentous actin cytoskeleton is apicobasally polarized and shows circumferential organization. Cytokeratins are the main intermediate filaments. The matrix-binding sites are on the basal face, mediating adhesion mainly to the basal lamina protein, laminin. In contrast, mesenchymal cells form a diffuse network with certain points on their surface adhering to their neighbors. Actin filaments form a dense cortical network of interacting fibers, and perhaps trans-cytoplasmic actin bundles. Vimentin is prominently expressed as an 
intermediate filament. Contact sites to the extracellular matrix (ECM) are widely distributed all around the cells. The ECM forms a dense meshwork involving proteins like collagens and fibronectin. In contrast to epithelial cells, mesenchymal cells also have a more extended and elongated shape, and they have front-to-back leading edge polarity (Tarin et al. 2005; Lee et al. 2006; Thiery and Sleeman 2006; Hugo et al. 2007; Berx et al. 2007). In clinical practice pathologists use the terms "sarcomatous/sarcomatoid dedifferentiation" (i.e., "—resembling a sarcoma-", a malignant mesenchymal tumor) or anaplasia (meaning "to form backward-") (Van Marck and Bracke 2005). EMT is not considered a requisite for invasion and metastasis, but compelling evidence shows that it can play an important role in determining the dissemination of tumors (Berx et al. 2007). In animal models, single non-dividing migratory cells delaminate from primary tumors as evidenced by powerful imaging techniques such as multiphoton microscopy (Condeelis and Segall 2003). The characterization of specific markers will undoubtedly help to identify the nature and origin of all mesenchymal-like cells found in the stroma and near the primary tumor.

\section{Molecular and functional signatures of EMT}

A key to EMT is the reduction of cell-cell adhesion by transcriptional repression of cadherins (adherens junctions), occludin and claudin (tight junctions), and desmoplakin (desmosomes) (Fig. 1). The Armadillo $\beta$-catenin protein is often lost from the cadherin-mediated cell-cell contacts and shuttles to the nucleus to potentiate EMT signaling events (Stemmer et al. 2008). Circumferential F-actin fibers of the cytoskeleton are replaced by a Rhomediated network of stress fibers (occasionally positive for the myofibroblast marker $\alpha$-smooth muscle actin), at the tip of which ECM adhesion molecules localize, including integrins $\alpha_{\mathrm{v}} \beta_{6}$, fascin, and integrin linked kinase (ILK) (Bates et al. 2005; Vignjevic et al. 2007; Fuchs et al. 2008). These changes are sufficient for the cells to separate, lose apicobasal polarity and gain a more spindle shape, all facilitating cellular migration (Hugo et al. 2007; Lee et al. 2006). However, cells produced by EMT are not always motile and invasive. In fibrotic kidney, fibroblasts derived from tubular epithelia do not migrate (Kalluri and Neilson 2003). The expression of intermediate filaments is also changing during EMT, with vimentin being typical of mesenchymal cells and different types of cytokeratin being characteristic of epithelial cells. Matrix metalloproteases (MMP's) such as MMP-1, -2, -3, -7 and -14 are frequently upregulated during EMT, potentially enabling cells to detach from each other (via cadherin ectodomain shedding) and to penetrate the basement membrane. ECM synthesis changes from basal lamina proteins to interstitial forms including collagen type I, fibronectin, secreted protein acidic and rich in cysteine (SPARC) and tenascin C (Nguyen et al. 2005). Furthermore, matricellular proteins, which bridge the functional and physical gap between ECM-associated proteins and cell surface proteins, were recently implicated in the EMT process. This is exemplified by induction of EMT in epithelial MCF-7 breast cancer cells by loss of the Wntinduced signaling protein (WISP)-2 (Fritah et al. 2008). E-cadherin (epithelial cadherin) is essential for maintaining epithelial integrity of many embryonic and adult tissues. It has been known for a long time that the loss of epithelial differentiation in carcinomas is linked to abnormal, tumorrestricted reduction in the expression of E-cadherin (Semb and Christofori 1998; Strumane et al. 2004). Multiple mechanisms of E-cadherin loss have been described, including abnormal proteolytic cleavage, loss of heterozygosity and inactivating E-cadherin mutations, but lately the mechanism of transcriptional silencing is acquiring much attention. The loss of E-cadherin expression at the transcript level was first identified in several human cancer cell lines and later in different human cancers, including prostate, breast, colorectal and thyroid cancers (Reviewed in Van Aken et al. 2001; Strumane et al. 2004). This initiated the elaborate analysis of the mouse E-cadherin promoter, which has been of primary importance in unraveling the regulatory mechanisms of E-cadherin transcription. Analysis of the mouse proximal E-cadherin promoter identified E-box sequences that determine epithelium-specific expression (Behrens et al. 1991). Inactivation of these consensus E-box sequences resulted in transcriptional activity of the E-cadherin promoter in mesenchymal cells, which indicated the existence of repressors that silence E-cadherin expression in non-epithelial cells. A major breakthrough was the identification of a series of transcriptional repressors, such as Snail, Slug, SIP1/ZEB2 (Smad Interacting Protein)/(Zinc finger E-box Binding homeobox), deltaEF1/ ZEB1 and the basic helix-loop-helix (HLH) transcription factor E47, which can directly bind the E-cadherin promoter and repress E-cadherin transcription (Cano et al. 2000; Batlle et al. 2000; Comijn et al. 2001; Eger et al. 2005). Importantly, these E-cadherin repressors have been linked to particular EMT processes during development (Nieto 2002; Vandewalle et al. 2005; Van de Putte et al. 2003). Indeed, overexpression of these transcription factors in epithelial cells not only results in loss of E-cadherin expression but also reprograms the cells toward a mesenchymal cell state. During EMT, transcription factors that reduce E-cadherin expression also downregulate other adhesion molecules and induce mesenchymal features in a coordinated manner (Cano et al. 2000; Vandewalle et al. 2005; De Craene et al. 2005; Aigner et al. 2007). Conditional expression of Snail in DLD-1 colorectal cancer cells 
induces invasion of elongated, solitary cells into collagen type I gels $(1 \mathrm{mg} / \mathrm{ml})$ as evidenced by H\&E stained paraffin sections from 14 day cultures (Fig. 2). In the absence of Snail expression DLD-1 cells form a monolayer on top of collagen type I gels. Interestingly, it was recently shown that knock-down of deltaEF1/ZEB1 in dedifferentiated human epithelial colon and breast cancer cell lines results in re-expression of E-cadherin and other epithelial differentiation markers (Eger et al. 2005; Spaderna et al. 2006, 2008). In addition, to the above-described transcription factors, several other factors that induce EMT with typical loss of E-cadherin expression have been identified, such as TWIST, homeobox (HOX)-B7, CArG box-binding factorA (CBF-A), Mesenchyme Forkhead 1 (FOXC2), and Krüppel-like factor (KLF)-8 (Venkov et al. 2007; Mani et al. 2007; Wu et al. 2006; Wang et al. 2007). Transrepression of E-cadherin transcription is accompanied by the induction of $\mathrm{N}$-cadherin (neural cadherin) or cadherin-11 expression. This so-called cadherin switch (Vandewalle et al. 2005) is believed to contribute to malignant cancer progression (Wheelock et al. 2008). The expression of these transcription factors seems to be regulated by pathways known to promote tumor progression, including transforming growth factor (TGF)- $\beta$, vascular endothelial growth factor and scatter factor/hepatocyte growth factor (SF/HGF) (reviewed in Peinado et al. 2007). For instance, TGF- $\beta$ mediates EMT by signaling via receptor similar to mothers against decapentaplegic (Smad)2/3 and through highmobility group AT-hook (HMGA)-2 family of nonhistone chromatin proteins, the latter of which coordinates the expression of both Snail and Slug and the basic HLH-transcription factors Twist and Id 2 (Thuault et al. 2006). Other recently described important modulators of EMT are small noncoding RNAs of 20- to 22-nucleotides (microRNAs, miRNAs) that inhibit gene expression at the post-transcriptional level: miR-141, miR-200b and miR-205 families control expression of ZEB1 and ZEB2 (Park et al. 2008; Gregory et al. 2008). Profiling miRNA expression of the NCI60 panel of human cell lines which are used for drug screening revealed that the miR-141 and miR-200b families of miRNAs were striking markers of the epithelial phenotype. Selective knockdown of miR-141, miR-200b and miR-205 family miRNAs was sufficient to reduce E-cadherin expression in a ZEB1/ZEB2-dependent way, leading to increased cell motility and thus EMT in epithelial MDCK3 and HCT116 cells. Conversely, ectopic expression of these miRNAs led to the re-expression of E-cadherin and epithelial phenotypes in MDCK cells that had undergone EMT and in mesenchymal MDA-MB-231 breast cancer cells (Park et al. 2008; Gregory et al. 2008). Each of the 400 miRNAs known to exist in mammalian cells has multiple targets, making them powerful regulators of complex processes such as differentiation and cancer progression. Indeed, a strong link between miRNA and human cancers has been established, as it has been demonstrated that miRNAs act either as oncogenes (e.g., miR155, miR-17-5p and miR-21) (He et al. 2005; Voorhoeve et al. 2006) or tumor suppressors (e.g., miR-15a, miR-16-1 and let-7) (Calin et al. 2002; Takamizawa et al. 2004; Johnson et al. 2007; Yanaihara et al. 2006).

\section{Extracellular cues regulating EMT}

Bi-directional communication between cancer cells and their microenvironment, profoundly influences their behavior and fate. Primary tumors are heterogenous and EMT is observed particularly at the cancer invasion front, suggesting the micro-environment as being essential in regulating EMT. For example, melanoma cells that give rise to invasive tumors when implanted into adult animals are reprogrammed into a non-aggressive phenotype when implanted into embryonic tissue (Hendrix et al. 2007). The stroma is essential for tissue integrity and in cancer it drives tissue invasion. Myofibroblasts (also called cancer-associated fibroblasts) are important components of the tumor stroma at the invasion front (De Wever and Mareel 2003; De Wever et al. 2008). In squamous cervix and colon carcinomas, Snail expression is restricted to cancer cells near stromal cells (Francí et al. 2006). Similarly, cancer cells accumulating nuclear $\beta$-catenin are distributed throughout the tumor mass but particularly along the invasion front (reviewed by Le et al. 2008). These results suggest that myofibroblasts docking at the invasion front regulate EMT of nearby cancer cells. This myofibroblast-induced EMT may be caused by transient heterotypic cell-cell contacts or by paracrine signals. In vitro, paracrine factors derived from breast tumor myofibroblasts induce EMT in PMC42LA breast cancer cells, with upregulation of vimentin, loss of E-cadherin staining at cellular contacts and increased nuclear $\beta$-catenin signaling (Lebret et al. 2007). We previously demonstrated that tenascin $\mathrm{C}$ and SF/HGF produced by myofibroblasts provide convergent pro-invasive signaling to colon cancer cells (De Wever et al. 2004; Denys et al. 2008). ECM remodeling by myofibroblasts is implicated in progression of prostate cancer xenografts (Verona et al. 2007). Furthermore, increased collagen production and expression of $\alpha 11 \beta 1$ integrin in combination with $\alpha$-SMA mediated contractility has a profound effect on the tumor stiffness that is linked with malignancy (Zhu et al. 2007). Matrix stiffness perturbs epithelial morphogenesis by clustering integrins to enhance ILK activation and increase Rho-kinase (ROCK)-generated contractility and focal adhesions (Paszek et al. 2005; Hannigan et al. 2005). Furthermore, engagement of collagen-binding integrins promotes MMP-9-dependent shedding of the E-cadherin 


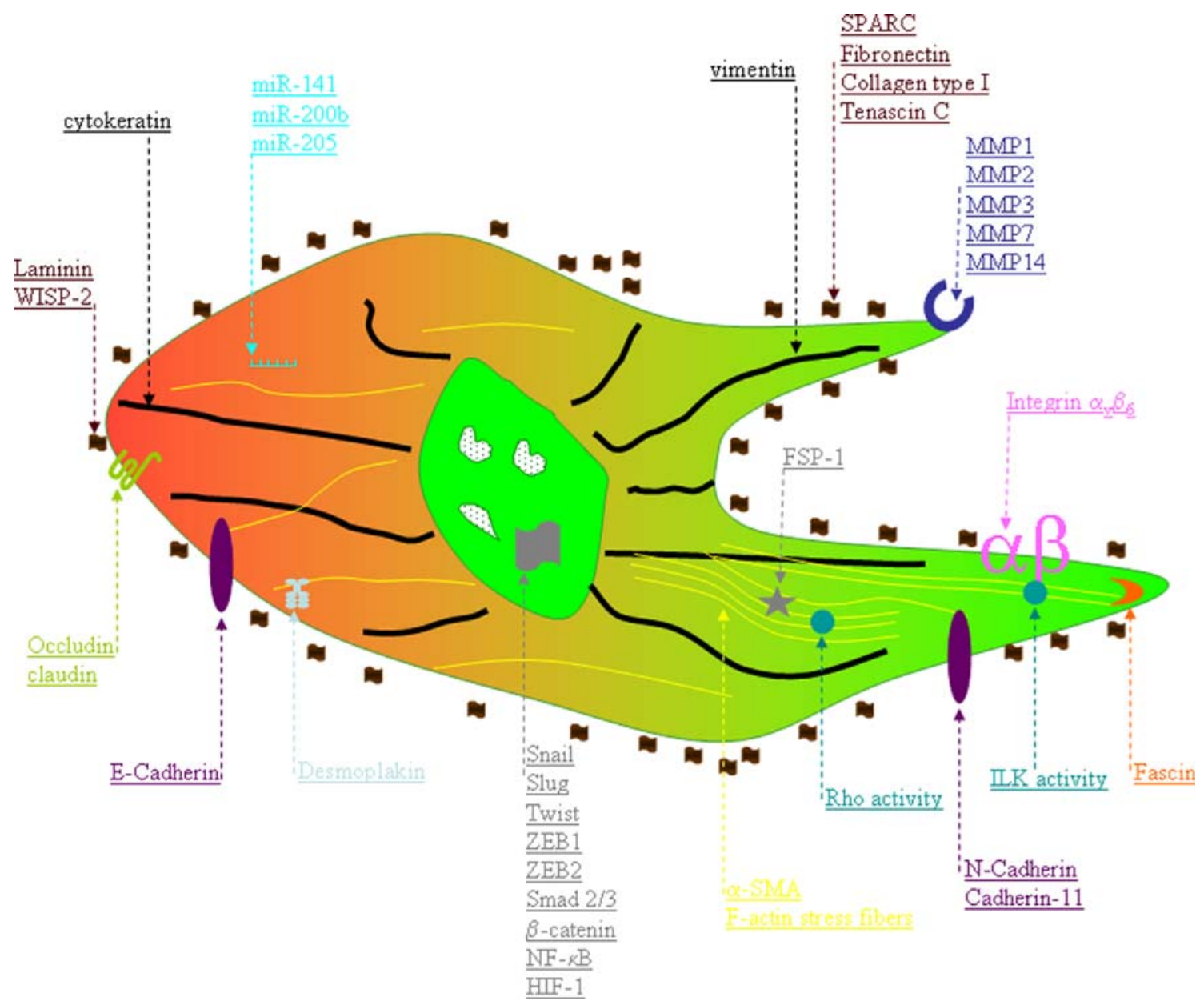

Fig. 1 Schematic representation of EMT markers. Upregulated factors implicated in cytoskeletal changes and the mesenchymal phenotype ( $g$ reen side) and repressed markers (red side) implicated in the maintenance of the epithelial phenotype. See text for more details

ectodomain in ovarian carcinoma cells (Symowicz et al. 2007). Another factor that is receiving considerable attention as an inducer of tumor metastasis is hypoxia (reduced oxygen). There is a strong correlation between tumor hypoxia on the one hand, and metastasis, poor prognosis and patient mortality on the other. This hypoxic response is mainly regulated by the hypoxia-inducible factor (HIF-1), a basic HLH transcription factor composed of two subunits, HIF- $1 \alpha$ and HIF- $1 \beta$. The HIF- $1 \alpha$ subunit is regulated by oxygen tension, whereas HIF-1 $\beta$ is constitutively expressed. In breast MCF-7 and ovarian SKOV-3 carcinoma cell lines, Notch signaling is required to convert the hypoxia stimulus into a Snail dependent EMT program leading to increased motility and invasion (Sahlgren et al. 2008). Similarly, hypoxia or overexpression of HIF- $1 \alpha$ promotes EMT and metastatic phenotypes in human carcinoma cells via direct induction of the E-cadherin repressor and EMT inducer Twist by direct binding of HIF- $1 \alpha$ at the hypoxia response element in the TWIST proximal promoter (Yang et al. 2008). Accordingly, E-cadherin levels were down-regulated while vimentin and $\mathrm{N}$-cadherin were induced in these hypoxic cancer cells. Importantly, these observations were extended in hypoxic human breast cancer cells showing cellular scattering, cell dissemination in vivo, high vimentin levels, translocation of E-cadherin in intracellular pools and nuclear translocation of the EMT inducer Snail (Lester et al. 2007). Furthermore, co-expression of HIF- $1 \alpha$ and TWIST in primary tumors of head and neck cancer patients correlates with metastasis (Yang et al. 2008).

\section{EMT signatures at early stages of carcinogenesis and cancer recurrence in vivo}

Epidemiologic and clinical studies indicate that a strong association exists between estrogen exposure and increased breast cancer risk. Estrogen and/or estrogen metabolites may act as procarcinogens through ER- $\alpha$-dependent or independent mechanisms, and may induce genotoxic effects to initiate breast, prostate or other cancers (Yager and Davidson 2006; Huang et al. 2007). In support of these 
Fig. 2 Conditional expression of Snail stimulates invasion. Light microscopy of H\&E stained paraffin sections from doxycyclin-inducible $10^{5}$ DLD1TR21-hSnailMyc/His colon cancer cells that were seeded on a layer of collagen type I ( $1 \mathrm{mg} /$ $\mathrm{ml})$ in the absence (A and $\mathrm{B}$ ) or presence $(\mathrm{C}$ and $\mathrm{D})$ of doxycyclin; fixation was after 14 days culture with medium refreshments every $48 \mathrm{~h}$. Arrows are invasive DLD-1 cells. Scale bar $=50 \mu \mathrm{m}$

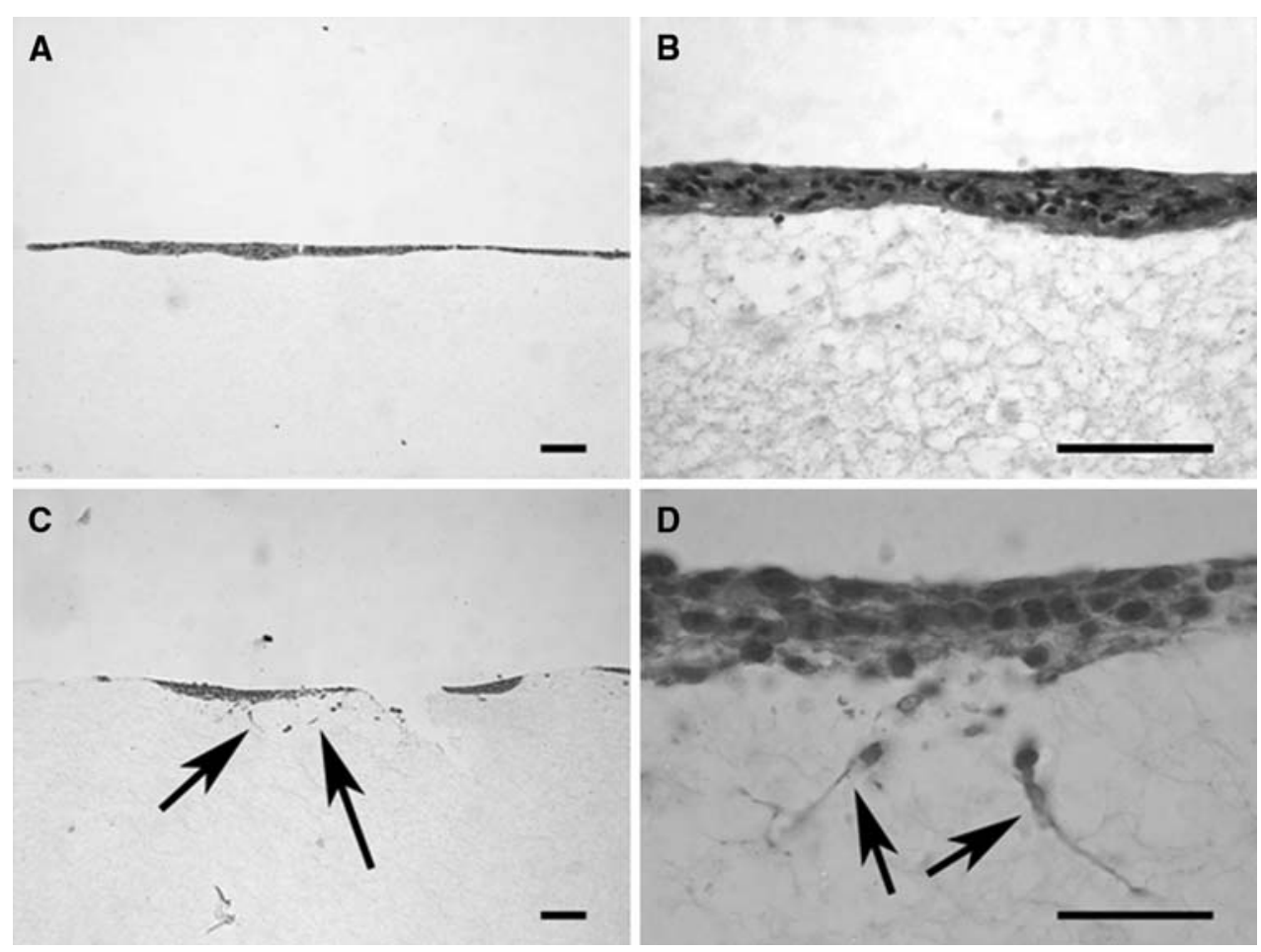

observations, long-term treatment of spontaneously immortalized human breast epithelial cells by estradiol induced several phenotypic traits characteristic of EMT, including invasiveness, lower expression of the epithelial markers E-cadherin, keratins, and induction of Snail, vimentin, and the EMT inducer TGF- $\beta$ (Huang et al. 2007).

To identify early events associated with myc-induced breast cancer, mouse mammary epithelial cells and stromal cells were distinguished using fibroblast specific protein (FSP) and epithelial-specific whey acidic protein (WAP) promoter driving transgenic expression of Cre recombinase constructs in transgenic animals, respectively (Trimboli et al. 2008). These two lineages were identified histologically by expression of the LacZ reporter gene from the Rosa26 ${ }^{\text {LoxP }}$ locus. Of note, early EMT events occurred in $25-50 \%$ of myc-initiated breast cancer in WAP-myc; FSPcre; Rosa26 ${ }^{\text {LoxP }}$ mammary glands. The frequency of EMT in tumor mice with the FSP-cre transgene was slightly higher than in mice with the WAP-cre transgene, consistent with the concept that $F s p-1$ expression is an early event in the EMT process. The MYC locus in the 131 patient samples was therefore analyzed for genome-wide LOH, using the adjacent polymorphic marker D8S1128. Trimboli et al. (2008) concluded that MYC amplification is associated with a predisposition of the epithelium to undergo EMT in human breast cancer.

Early appearance of several molecular alterations characteristic of EMT has been described in benign adenomas of the multiple intestinal neoplasia (Min) mouse model of familial adenomatous polyposis disease (Chen et al. 2008).
Inactivation of the adenomatous polyposis coli tumor suppressor protein in this preclinical model recapitulates early events underlying the progression of human colorectal cancer. A strong vimentin signal was observed in the cytoplasm of Min colonic neoplastic cells with characteristic epithelial organization in 74 out of 79 tumors. Vimentin staining was absent from the adjacent normal epithelium. Microadenomas involving only three to five crypts in the colon and small intestine displayed elevated vimentin mRNA levels, suggesting that the classical EMT marker, vimentin can be detected at an early stage of tumorigenesis. Of note, Min mice on a tumor-resistant genetic background have reduced tumor multiplicities, longer life-span, and develop invasive intestinal tumors, that reached the submucosa and muscle layers. In this model, immunohistochemistry demonstrated strong vimentin expression in the epithelia of the primary tumor and in the neoplastic cells invading the submucosa and muscular layers (Chen et al. 2008). Vimentin expression was not systematically distributed in all neoplastic cells, but was present in patches in both central and peripheral tumor regions.

Breast cancer recurrence is an essential clinical manifestation of tumor progression and represents the principal cause of death from this disease. Using a conditional transgenic HER2/neu mouse model showing recurrence of HER2/neu-induced mammary tumors, Moody et al. (2005) demonstrated that the transcriptional repressor Snail is spontaneously upregulated in recurrent tumors in vivo and that recurrence is accompanied by EMT as evidenced by spindle shaped morphology with downregulation of 
cytokeratin and E-cadherin and upregulation of FSP. Furthermore, Snail is sufficient to promote recurrence of mammary tumors in vivo, and high levels of Snail are predictive of shorter relapse-free survival in breast cancer patients.

\section{Pathological signatures of EMT in tissue samples}

Normal epithelial cells are incapable of invasion; they can move laterally in the plane of the epithelium while retaining adhesion to the underlying basement membrane. Active movement in other directions appears to be forbidden to them. Such departures from the plane of an epithelium depend on the acquisition of mesenchymal cell traits (and on the shedding of some of their native epithelial characteristics). As more mesenchymal traits are acquired, it becomes more difficult for the pathologist to distinguish these cells from the true mesenchymal cells that surround the neoplastic cells. This is especially important to determine the presence of cancer cells at the resection margins of a tumor. Figure 3 shows an H\&E staining of a basal cell carcinoma with collective invading cancer cells and single migratory cancer cells released from the tumor mass. The analogy with mesenchymal fibroblasts or myofibroblasts present in the ECM is striking. Immunohistochemistry can help distinguish between cancer cells undergoing EMT and stromal fibroblasts, but it must be pointed out that most cancer cells undergoing EMT partially shut down epithelial markers while acquiring mesenchymal markers. Traditionally, most studies have been done by looking at the expression of the intermediate filaments, cytokeratin and vimentin. Routine immunohistochemistry employs a mixture of two different clones of monoclonal antibodies, AE1 and AE3 which cover most keratin subtypes (Goddard et al. 1991). The emergence of vimentin in epithelial cells of breast tumor correlates with a shorter post-operative survival of patients. Furthermore, the keratin/vimentin expression ratio is more predictive of a worse prognosis than vimentin expression alone (Thomas et al. 1999). In cervical cancer, vimentin expression is present in invasive carcinomas and in their lymph node metastases, but not in intraepithelial neoplasia precursor lesions (Gilles et al. 1996). In villous human adenomas, which show high-grade dysplasia, the vimentin signals were negative in some samples, whereas others showed strong, patchy staining. Expression of E-cadherin varied inversely with vimentin expression independently of Snail and Twist. Conversely, vimentin expression correlated with Wnt and TGF- $\beta$ signaling and with reduced levels of the Ki-67 proliferation marker (Chen et al. 2008). Cadherin switching may provide adhesion properties more suitable for a migrating cell. Reduced E-cadherin expression and gain of N-cadherin expression in cancer cells may be the result of EMT which is very difficult to detect in vivo. Double labeling of frozen sections with specific $\mathrm{E}$ - and $\mathrm{N}$-cadherin antibodies show that invasive micropapilary carcinoma, which metastasize easily to lymph nodes, contains cancer cells that are positive for N-cadherin, E-cadherin or both (Agiostratidou et al. 2007). In agreement with these findings, other researchers have observed $\mathrm{N}$-cadherin expression in breast, colon, gastric, esophageal, pancreatic and prostate tumors (reviewed in Van Aken et al. 2001). The immunohistochemical staining reaction of $\beta$-catenin in normal epithelium and in most non-invasive carcinomas, is predominantly membranous, sometimes with faint cytoplasmic staining. In EMT, an aberrant expression can be seen, with sole cytoplasmic and/or nuclear staining. This supports the notion that competition between different cellular partners for the cytoplasmic pool of $\beta$-catenin influences its final incorporation either in cell adhesion or in signal transduction mechanisms. Nuclear accumulation of $\beta$-catenin is observed in colorectal cancer cells distributed along the invasion front but not in the tumor center (Hlubek et al. 2007). Furthermore, gene expression profiling revealed overexpression of EMT genes at the invasion front such as TWIST, FSP and tenascin C. Indeed, when $\beta$-catenin is released from the adherens junctions, it can enter the nucleus and lead to a transcription of putative invasion related genes. Another cadherin-binding protein, p120catenin, shifts it localization from cell-cell junctions to the cytoplasm and this correlates with colon cancer progression and patient survival (Bellovin et al. 2005). Recent research has also documented the role of the Snail superfamily in mediating the loss of epithelial adhesion molecules. Immunohistochemical positivity of nuclear Snail correlates with increased vimentin and decreased E-cadherin expression in esophageal squamous cell carcinoma (Usami et al. 2008). The different repressors of E-cadherin transcription have already been associated with progression of different cancer types, e.g., breast (Cheng et al. 2001; Blanco et al. 2002; Moody et al. 2005; Yang et al. 2004; Martin et al, 2005) and gastric cancer (Rosivatz et al. 2002). Although the correlative expression data of the different E-cadherin repressors versus E-cadherin are overwhelming, care should be taken with their interpretation because many of these data are based on RT-PCR and on the use of antibodies with undefined specificity.

A large-scale tissue microarray-based immunohistochemical study of 479 invasive breast carcinomas revealed upregulation of mesenchymal markers (vimentin, $\alpha$-SMA, $\mathrm{N}$-cadherin and cadherin-11) and overexpression of proteins involved in ECM remodeling and invasion (SPARC, laminin and fascin), together with reduction of characteristic epithelial markers (E-cadherin and cytokeratin) particularly in breast tumors with the "basal-like phenotype" (Sarrió et al., 2008). Gene expression analysis using cDNA 


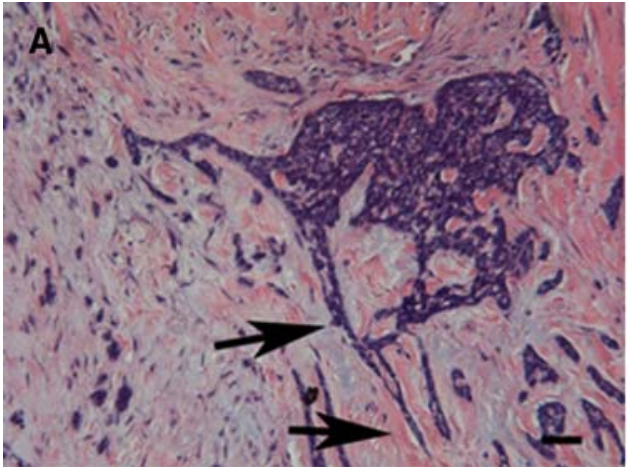

Fig. 3 Histology of basal cell carcinoma. Hematoxylin and eosin staining of a basal cell carcinoma showing the collective invasion of epithelial cancer cells into the extracellular matrix (arrows, panel A). Single cancer cells detached from the tumor mass and showing traits of

Oncochip microarray of metastatic versus non-metastatic melanomas identified differentially expressed genes implicated in EMT. Validation of these expression data in an independent series of melanomas using tissue microarrays confirmed that the expression of a set of proteins included in the EMT group (N-cadherin, osteopontin and SPARC) was significantly associated with metastasis development (Alonso et al. 2007). A similar oligonucleotide microarray study on papillary thyroid carcinoma from central and invasive regions and of normal thyroid tissue was performed. The invasion fronts were consistently characterized by the presence of mesenchymal markers and absence of epithelial markers. Furthermore, immunohistochemical analysis revealed that overexpression of vimentin associated with papillary thyroid carcinoma cell invasion (Vasko et al. 2007). Molecular classification of fresh-frozen and formalin-fixed head and neck squamous cell carcinomas showed that genes involved in EMT are the most prominent molecular characteristics of high-risk tumors (Chung et al. 2006). In conclusion, we strongly insist that the occurrence of the EMT signature should be explored in large-scale studies of human clinical tumors in order to predict their metastatic potential.

\section{Pathological signatures of EMT in biological fluids}

A number of molecules related to EMT can be assessed in biological fluids from cancer patients. Particularly in serum they reflect either the pathogenesis or the consequences of the phenomenon. Table 1 summarizes their applications in different types of cancer.

Scatter factor/hepatocyte growth factor concentrations in serum are correlated with metastatic spread, they possess prognostic value, and they are useful for monitoring therapy. They can also be used as a urine parameter for diagnosis of transitional carcinoma of the bladder. Fibroblast

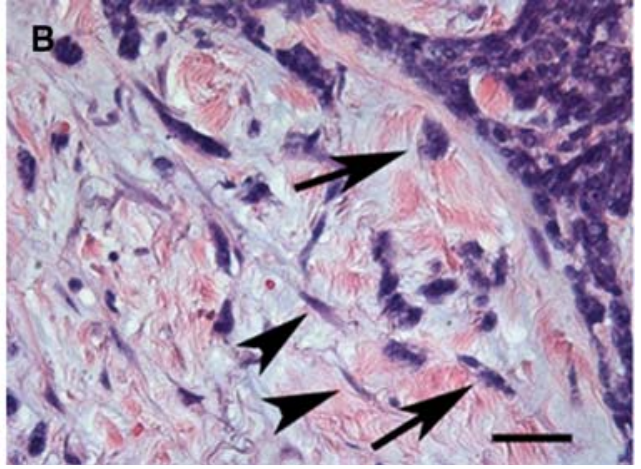

epithelial-mesenchymal transition are indicated by arrows (panel B) Stromal (myo)fibroblasts are indicated by arrowheads. Scale bars $=50 \mu \mathrm{m}$

growth factor-2 (FGF-2), another tyrosine kinase receptor ligand, is an endothelial-to-mesenchymal transformation marker, its serum concentrations correlate with tumor growth rate, volume, grading and staging. Its main clinical usefulness, however, resides in monitoring the effect of angiogenesis inhibitors. In prostatic cancer an inverse correlation between prostate-specific antigen (PSA) and FGF2 has repeatedly been observed (Usami et al. 2008). While the EMT inducer TGF- $\beta$ as a circulating marker is difficult to interprete, the serum concentrations of its functional activators, MMP-9 and CD44 (mainly its spliced isoform v6), have proven to possess prognostic information. Assessment of the urine concentrations of MMP-9 was claimed to contribute to the diagnosis of bladder cancer. Circulating tenascin-C, a matricellular protein acting in concert with SF/ HGF, can discriminate between good and bad prognosis in numerous cancers, and its cut-off level was determined at $96 \mathrm{ng} / \mathrm{ml}$. Tenascin-C serum concentrations also correlated with the vascularization of the tumors. A central player in cancer progression is $p 53$, and this tumor suppressor's level in circulation was found to be higher in cancer patients than in normal individuals. This is presumably the result of the increased biological half-life of many p53 mutants. Moreover, mutations in exons 5 and 6 are particularly immunogenic, and elicit detectable auto-immune anti-p53 antibodies in the circulation (IgM and $\operatorname{IgG}$ ). Although p53 and its antibodies were shown to correlate with prognosis and therapeutic response of head- and neck cancer, their major applicability is in epidemiological studies, where mutagenic pressure from the environment has to be assessed.

The switch from E- to N-cadherin is considered typical for EMT, and enzymatically shed, soluble ectodomains from both cadherins have been detected at elevated levels in the serum of cancer patients reviewed in (De Wever et al. 2007). Conceptually the measurement of soluble E-cadherin (sE-cad) may be less straightforward, because 
Table 1 Organ-related application of circulating EMT markers

\begin{tabular}{|c|c|c|c|c|c|c|c|c|c|c|c|c|c|c|c|c|}
\hline $\begin{array}{l}\text { Organ or tissue/ } \\
\text { marker }\end{array}$ & $\mathrm{SF} / \mathrm{HGF}$ & FGF-2 & MMP-9 & CD44v6 & Tenascin-C & $\mathrm{p} 53$ & Anti- p53 & sN-cad & sE-cad & PSA & hK4 & CEA & CA $15-3$ & CA 19-9 & CA125 & AFP \\
\hline Bile ducts & & & & & & & & & & & & bf & & bi & & $\mathrm{bp}$ \\
\hline Bladder & $a^{1}$ & & $r^{1}$ & $\mathrm{v}$ & $\mathrm{aa}^{4}$ & & al & & $a v^{1}$ & & & bf & & & & \\
\hline Breast & $\mathrm{b}$ & $\mathrm{h}$ & $\mathrm{s}$ & $\mathrm{w}$ & & ae & am & at & & $\mathrm{bb}$ & & bf & bh & bj & & \\
\hline Cervix & & $\mathrm{i}$ & & & & & & & & & & bf & & bk & bn & \\
\hline Colorectum & $\mathrm{c}$ & $\mathrm{j}$ & & & $\mathrm{ab}$ & af & an & & aw & & & bg & & bi & & $\mathrm{bp}$ \\
\hline Endometrium & & $\mathrm{k}$ & & & & & & & & & & bf & & & bn & \\
\hline Esophagus & d & & & & & ag & ao & & & & & bf & & & & \\
\hline Head and neck & & 1 & $\mathrm{t}$ & $\mathrm{x}$ & $\mathrm{ac}$ & & & & & & & bf & & & & \\
\hline Kidney & & $\mathrm{m}$ & & & & & & & & & & bf & & & & $\mathrm{bq}$ \\
\hline Liver & $\mathrm{e}$ & & & & & & $\mathrm{am}$ & & & & & bf & & bi & & bp \\
\hline Lung (small cell) & f & & & & & ah & ap & & & & & & & bk & & \\
\hline $\begin{array}{l}\text { Lung (non- } \\
\text { small cell) }\end{array}$ & & $\mathrm{n}^{2}$ & $\mathrm{u}$ & & ad & ai & $\mathrm{aq}$ & & $a x$ & & & bf & & bk & & \\
\hline Mesothelium & & & & & & & & & & & & bf & & & bo & \\
\hline Ovary & & o & & $\mathrm{y}$ & & & & & ay & & bd & bf & & $\mathrm{bm}$ & bn & \\
\hline Pancreas & & & & & & & ar & au & & & & bf & & bi & & $\mathrm{bp}$ \\
\hline Prostate & & $\mathrm{p}$ & & & & aj & as & at & $\mathrm{az}$ & $\mathrm{bc}$ & be & bf & & & & \\
\hline Stomach & $\mathrm{g}$ & & & $z^{3}$ & & & & & ba & & & bf & & bi & & $\mathrm{bp}$ \\
\hline Testis & & & & & & & & & & & & bf & & & & br \\
\hline Thyroid & & $\mathrm{q}$ & & & & ak & & & & & & bf & & & & \\
\hline
\end{tabular}

References are a Rosen et al. 1997, b Sheen-Chen et al. 2005, c Dluzniewska et al. 2002, d Ren et al. 2005, e Chau et al. 2008, f Takigawa et al. 1997, g Tanaka et al. 2004, h Granato et al. 2004, i Sliutz et al. 1995, j George et al. 2002, k McMeekin et al. 2007, 1 Homer et al. 2002, m Dosquet et al. 1997, n Ueno et al. 2001, o Le Page et al. 2006, p Meyer et al. 1995, q Vesely et al. 2004, r Nutt et al. 2003, s Somiari et al. 2006 , t Patel et al. 2007, u Mihaylova et al. 2007, v Lein et al. 1997, w Li et al. 2008, x Kawano et al. 2005, y Stickeler et al. 2000, z Saito et al. 1998, aa Gazzaniga et al. 2005, ab Takeda et al. 2007, ac Pauli et al. 2002, ad Ishiwata et al. 2005, ae Adzic et al. 2004; af Famulski et al. 2006, ag Attallah et al. 2003, ah Segawa et al. 1997, ai Luo et al. 1994, aj Suwa et al. 1997, ak Kolomecki et al. 2005, al Gumus et al. 2004, am Müller et al. 2006, an Tang et al. 2001, ao Bergström et al. 2004, ap Murray et al. 2000, aq Bergqvist et al. 2004, ar Laurent-Puig et al. 1995, as Suzuki et al. 2004, at Derycke et al. 2006, au De Wever et al. 2007, av Shariat et al. 2005, aw Velikova et al. 1998, ax Charalabopoulos et al. 2006, ay Gadducci et al. 1999, az Kuefer et al. 2005, ba Chan et al. 2005, bb Hautmann et al. 2000, bc Polascik et al. 1999, bd Obiezu and Diamandis 2005, be Bracke 2006, bf Chevinsky 1991, bg Thomson et al. 1969, bh Hilkens et al. 1987, bi Ritts Jr et al. 1984, bj Papantoniou et al. 2006, bk Abe et al. 1999, bl Molina et al. 1989, bm Gadducci et al. 2004, bn Bast et al. 1998, bo Creaney et al. 2007, bp McIntire et al. 1975, bq Parikh et al. 2007, br Elgort et al. 1973

1 Assay on urine

${ }^{2}$ Decreased concentrations indicate better prognosis

${ }^{3}$ Also valid for CD44v5

${ }^{4}$ Expressed by circulating cancer cells

E-cadherin is downregulated in carcinomas. Soluble Ncadherin (sN-cad), however, may be a very sensitive circulating marker, because it is upregulated in cancer cells and in stromal myofibroblasts. Two members of the kallikrein family, hK3 (or PSA) and hK4 (prostase) were shown to induce EMT in prostatic carcinoma cells in vitro (Lawrence et al. 2007), and both members are tumor markers for prostatic carcinoma. PSA is not only useful for the monitoring and follow up of therapy, it even contributes to the diagnosis and staging of prostatic carcinoma patients. Additional measurements have refined the interpretation of PSA values. These additional measurements include the rate of the PSA increase (more or less than $0.75 \mathrm{ng} / \mathrm{ml}$ or $20 \%$ a year), PSA density (serum PSA/ prostatic volume), age-related reference values, determi- nation of free/complexed PSA in serum and neural network assistance.

Loss of epithelial cell polarity and of junctional contacts in cancer, in combination with basement membrane breakdown, removes the barriers for apical markers to diffuse into the extracellular fluids. Some high molecular weight apical mucins, which normally circulate at extremely low concentrations, are sensitive markers for loss of cell-cell contact in cancer. Nowadays, they belong to the most frequently prescribed tumor markers in clinical chemistry, and are known as carcino-embryonic antigen (CEA), CA 15-3, CA 19-9 and CA 125. As a result of cell-cell contact loss in hepatocellular carcinoma, $\alpha$-fetoprotein (AFP) is upregulated (Gleiberman et al. 1989), and has proven to be an excellent serum marker for this type of cancer. 


\section{Does EMT affect cancer treatment regimens?}

Selective tyrosine kinase inhibitors are promising to treat cancers driven by activated tyrosine kinases such as Bcr-Abl in chronic myelogenous leukemia, c-Kit in gastrointestinal stromal tumors and EGF receptor (EGFR) in non-small cell lung cancer (NSCLC). Gefitinib (Iressa) and erlotinib (Tarceva) are selective inhibitors of the EGFR receptor tyrosine kinase and is currently used to treat NSCLC patients (Guo et al. 2008). Although most NSCLC tumors express EGFR, only a fraction of patients with tumors dependent on EGFR for growth and survival respond clinically to EGFR inhibitors. These tumors appear to contain EGFR-activating mutations or have undergone amplification of EGFR gene copy number. Furthermore, a subset of non-small cell lung carcinomas that do not respond to erlotinib therapy have low levels of E-cadherin and higher levels of mesenchymal type transcripts such as vimentin and fibronectin (Thomson et al. 2005). The bulk of Thomson's evidence is derived from NSCLC cell lines, but some confirmatory evidence comes from immunohistochemical staining of sections of human tumors (Yauch et al. 2005). Furthermore, ILK-mediated EMT predicts hepatocellular carcinoma sensitivity to EGFR-targeted therapies (Fuchs et al. 2008).

Alternatively, many routine cancer treatments may stimulate EMT and thus enhance invasion and metastasis. Chronic chemotherapy with oxaliplatin (a third generation platinum compound) induces EMT in colorectal cancer cell lines (Yang et al. 2006). In another example, ionizing radiation induces changes associated with EMT such as increased migration, F-actin stress fiber formation, and disturbed E-cadherin pattern in A549 lung epithelial cells in vitro (Jung et al. 2007). Human malignant gliomas are lethal neoplasms. Involved-field radiotherapy is the most important therapeutic measure. Most relapses originate from the close vicinity of the irradiated target field. Interestingly, sublethal doses of irradiation enhance the migration and invasiveness of human malignant glioma cell lines in vitro. IR-induced migration is p53-independent, and involves enhanced expression of $\alpha \mathrm{v} \beta 3$ integrin, altered MMP-2 and MMP-9 expression and activity profiles, altered expression of membrane type $1 \mathrm{MMP}$ and tissue inhibitor of metalloproteinases-2, and altered BCL-2/BAX balance favoring resistance to apoptosis (Wild-Bode et al. 2001). Current approaches to cancer treatment involving more intensive radiotherapy regimens have been suggested to be associated with a higher incidence of local or distant metastasis (Jung et al. 2007). Therefore, a subset of patients may benefit from a combination of radiotherapy and EMT inhibitors. We did not find prospective randomized clinical trials providing level 1 evidence in favor of or against such side effects of treatment so our discussion is admittedly speculative.
Epithelial-mesenchymal transition signatures can be exploited to enhance classical chemotherapy treatments. Gain of N-cadherin expression is a typical example of the EMT signature and it has been linked with drug resistance (Zhang et al. 2007). Interestingly, ADH-1 (an N-cadherin cyclic pentapeptide antagonist) sensitizes $\mathrm{N}$-cadherinexpressing melanoma cells to the anti-tumor activity of melphalan in melanoma models (Mariotti et al. 2007; Augustine et al. 2008). Recent work provides evidence to support the possibility of exploiting EMT as a potential therapeutic target in cancer (Sabbah et al. 2008).

\section{Conclusion}

Converging evidence using in vitro cell culture models, transgenic mouse models, gene signature microarray analysis and immunohistochemistry points out that EMT, amongst other mechanisms, is implicated in early steps of carcinogenesis, cancer cell invasion and metastasis and recurrence. The list of molecular signatures defining EMT is growing and will eventually lead to a clear definition useful for daily practice in pathology and clinical biology. Understanding the molecular basis of EMT is essential for designing small-molecule inhibitors targeting the EMT response. These can be used to enhance classical chemotherapy treatments.

Acknowledgments G. De Bruyne is gratefully acknowledged for reference management. This work was funded by Fonds Wetenschappelijk Onderzoek (FWO)-Vlaanderen (Brussels, Belgium), Geconcerteerde Onderzoek Aangelegenheden (GOA, University Ghent, Belgium). The Association for International Cancer Research (Scotland), the Scientific Exchange Program between the Flemish community and France (Grant I.2007.03) and FP7 (TUMIC) of the European Union. O. De Wever and B. De Craene were supported by Bijzonder Onderzoeks Fonds (BOF, University Ghent, Belgium).

\section{References}

Abe A, Nakano T, Morita S, Oka K (1999) Clinical evaluation of serum and immunohistochemical expression of SCC and CA19-9 in radiation therapy for cervical cancer. Anticancer Res 19:829836

Adzic M, Niciforovic A, Neskovic-Konstantinovic Z, Radojcic MB (2004) Superoxide dismutases and p53 protein levels in blood cells of breast cancer patients. J BUON 9:283-287

Agiostratidou G, Hulit J, Phillips GR, Hazan RB (2007) Differential cadherin expression: potential markers for epithelial to mesenchymal transformation during tumor progression. J Mammary Gland Biol Neoplasia 12:127-133

Aigner K, Dampier B, Descovich L, Mikula M, Sultan A, Schreiber M, Mikulits W, Brabletz T, Strand D, Obrist P, Sommergruber W, Schweifer N, Wernitznig A, Beug H, Foisner R, Eger A (2007) The transcription factor ZEB1 ( $\delta \mathrm{EF} 1)$ promotes tumour cell dedifferentiation by repressing master regulators of epithelial polarity. Oncogene 26:6979-6988 
Alonso SR, Tracey L, Ortiz P, Pérez-Gómez B, Palacios J, Pollán M, Linares J, Serrano S, Sáez-Castillo AI, Sánchez L, Pajares R, Sánchez-Aguilera A, Artiga MJ, Piris MA, Rodríguez-Peralto JL (2007) A high-throughput study in melanoma identifies epithelial-mesenchymal transition as a major determinant of metastasis. Cancer Res 67:3450-3460

Attallah AM, Abdel-Aziz MM, El-Sayed AM, Tabll AA (2003) Detection of serum $\mathrm{p} 53$ protein in patients with different gastrointestinal cancers. Cancer Detect Prev 27:127-131

Augustine CK, Yoshimoto Y, Gupta M, Zipfel PA, Selim MA, Febbo P, Pendergast AM, Peters WP, Tyler DS (2008) Targeting N-cadherin enhances antitumor activity of cytotoxic therapies in melanoma treatment. Cancer Res 68:3777-3784

Bast RC Jr, Xu FJ, Yu YH, Barnhill S, Zhang Z, Mills GB (1998) CA 125: the past and the future. Int J Biol Markers 13:179-187

Bates RC, Bellovin DI, Brown C, Maynard E, Wu B, Kawakatsu H, Sheppard D, Oettgen P, Mercurio AM (2005) Transcriptional activation of integrin $B 6$ during the epithelial-mesenchymal transition defines a novel prognostic indicator of aggressive colon carcinoma. J Clin Invest 115:339-347

Batlle E, Sancho E, Franci C, Dominguez D, Monfar M, Baulida J, Garcia de Herreros A (2000) The transcription factor Snail is a repressor of E-cadherin gene expression in epithelial tumour cells. Nat Cell Biol 2:84-89

Behrens J, Weidner KM, Frixen UH, Schipper JH, Sachs M, Arakaki N, Daikuhara Y, Birchmeier W (1991) The role of E-cadherin and scatter factor in tumor invasion and cell motility. EXS 59:109_ 126

Bellovin DI, Bates RC, Muzikansky A, Rimm DL, Mercurio AM (2005) Altered localization of p120 catenin during epithelial to mesenchymal transition of colon carcinoma is prognostic for aggressive disease. Cancer Res 65:10938-10945

Bergqvist M, Brattström D, Larsson A, Hesselius P, Brodin O, Wagenius $\mathrm{G}$ (2004) The role of circulating anti-p53 antibodies in patients with advanced non-small cell lung cancer and their correlation to clinical parameters and survival. BMC Cancer 4:66

Bergström S, Dreilich M, Wagenius G, Brattström D, Larsson A, Hesselius P, Bergqvist M (2004) The presence of anti-p53 antibodies in sera from patients with oesophageal carcinoma: correlation to treatment, tumour volume and survival. In Vivo 18:615620

Berx G, Raspé E, Christofori G, Thiery JP, Sleeman JP (2007) PreEMTing metastasis? Recapitulation of morphogenetic processes in cancer. Clin Exp Metastasis 24:587-597

Blanco MJ, Moreno-BuenoClin Exp Metastasis G, Sarrio D, Locascio A, Cano A, Palacios J, Nieto MA (2002) Correlation of Snail expression with histological grade and lymph node status in breast carcinomas. Oncogene 21:3241-3246

Bracke ME (2006) Tumour markers in andrology. In: Schill W-B, Comhaire FH, Hargreave TB (eds) Andrology for the clinician, Chapter II.3.6. Springer, Berlin, pp 415-425

Calin GA, Dumitru CD, Shimizu M, Bichi R, Zupo S, Noch E, Aldler H, Rattan S, Keating M, Rai K, Rassenti L, Kipps T, Negrini M, Bullrich F, Croce CM (2002) Frequent deletions and down-regulation of micro- RNA genes miR15 and miR16 at 13q14 in chronic lymphocytic leukemia. Proc Natl Acad Sci USA 99:15524-15529

Cano A, Pérez-Moreno MA, Rodrigo I, Locascio A, Blanco MJ, del Barrio MG, Portillo F, Nieto MA (2000) The transcription factor Snail controls epithelial-mesenchymal transitions by repressing E-cadherin expression. Nat Cell Biol 2:76-83

Chan AOO, Chu K-M, Lam SK, Cheung KL, Law S, Kwok K-F, Wong WM, Yuen MF, Wong BC-Y (2005) Early prediction of tumor recurrence after curative resection of gastric carcinoma by measuring soluble E-cadherin. Cancer 104:740-746

Charalabopoulos K, Gogali A, Dalavaga Y, Daskalopoulos G, Vassiliou M, Bablekos G, Karakosta A, Constantopoulos S (2006) The clinical significance of soluble E-cadherin in nonsmall cell lung cancer. Exp Oncol 28:83-85

Chau G-Y, Lui W-Y, Chi C-W, Chau Y-P, Li A-F, Kao H-L, Wu C-W (2008) Significance of serum hepatocyte growth factor levels in patients with hepatocellular carcinoma undergoing hepatic resection. Eur J Surg Oncol 34:333-338

Chen X, Halberg RB, Burch RP, Dove WF (2008) Intestinal adenomagenesis involves core molecular signatures of the epithelial-mesenchymal transition. J Mol Histol 39:283-294

Cheng C-W, Wu P-E, Yu J-C, Huang C-S, Yue C-T, Wu C-W, Shen C-Y (2001) Mechanisms of inactivation of E-cadherin in breast carcinoma: modification of the two-hit hypothesis of tumor suppressor gene. Oncogene 20:3814-3823

Chevinsky AH (1991) CEA in tumors of other than colorectal origin. Semin Surg Oncol 7:162-166

Chung CH, Parker JS, Ely K, Carter J, Yi Y, Murphy BA, Ang KK, ElNaggar AK, Zanation AM, Cmelak AJ, Levy S, Slebos RJ, Yarbrough WG (2006) Gene expression profiles identify epithelial-tomesenchymal transition and activation of nuclear factor- $\kappa \mathrm{B}$ signaling as characteristics of a high-risk head and neck squamous cell carcinoma. Cancer Res 66:8210-8218

Comijn J, Berx G, Vermassen P, Verschueren K, van Grunsven L, Bruyneel E, Mareel M, Huylebroeck D, van Roy F (2001) The two-handed $\mathrm{E}$ box binding zinc finger protein SIP1 downregulates E-cadherin and induces invasion. Mol Cell 7:1267-1278

Condeelis J, Segall JE (2003) Intravital imaging of cell movement in tumours. Nat Rev Cancer 3:921-930

Creaney J, van Bruggen I, Hof M, Segal A, Musk AW, de Klerk N, Horick N, Skates SJ, Robinson BWS (2007) Combined CA125 and mesothelin levels for the diagnosis of malignant mesothelioma. Chest 132:1239-1246

De Craene B, van Roy F, Berx G (2005) Unraveling signalling cascades for the Snail family of transcription factors. Cell Signal 17:535-547

De Wever O, Mareel M (2003) Role of tissue stroma in cancer cell invasion. J Pathol 200:429-447

De Wever O, Nguyen Q-D, Van Hoorde L, Bracke M, Bruyneel E, Gespach C, Mareel M (2004) Tenascin-C and SF/HGF produced by myofibroblasts in vitro provide convergent pro-invasive signals to human colon cancer cells through RhoA and Rac. FASEB J 18:1016-1018

De Wever O, Derycke L, Hendrix A, De Meerleer G, Godeau F, Depypere H, Bracke M (2007) Soluble cadherins as cancer biomarkers. Clin Exp Metastasis 24:685-697

De Wever O, Demetter P, Mareel M, Bracke M (2008) Stromal myofibroblasts are drivers of invasive cancer growth. Int J Cancer (in press)

Denys H, Derycke L, Hendrix A, Westbroek W, Gheldof A, Narine K, Pauwels P, Gespach C, Bracke M, De Wever O (2008) Differential impact of TGF- $\beta$ and EGF on fibroblast differentiation and invasion reciprocally promotes colon cancer cell invasion. Cancer Lett 266:263-274

Derycke L, De Wever O, Stove V, Vanhoecke B, Delanghe J, Depypere H, Bracke M (2006) Soluble N-cadherin in human biological fluids. Int J Cancer 119:2895-2900

Dluzniewska J, Zolich D, Polanski J, Zajac L, Sitkiewicz D, Lukomska B (2002) Hepatocyte growth factor levels in liver and blood, and post-operative liver cell proliferation in patients with benign and malignant liver tumors after partial hepatectomy. Med Sci Monit 8:690-696

Dosquet C, Coudert M-C, Lepage E, Cabane J, Richard F (1997) Are angiogenic factors, cytokines, and soluble adhesion molecules prognostic factors in patients with renal cell carcinoma? Clin Cancer Res 3:2451-2458

Eger A, Aigner K, Sonderegger S, Dampier B, Oehler S, Schreiber M, Berx G, Cano A, Beug H, Foisner R (2005) $\delta \mathrm{EF} 1$ is a transcriptional 
repressor of E-cadherin and regulates epithelial plasticity in breast cancer cells. Oncogene 24:2375-2385

Elgort DA, Abelev GI, Levina DM, Marienbach EV, Martochkina GA, Laskina AV, Solovjeva EA (1973) Immunoradioautography test for alpha-fetoprotein in the differential diagnosis of germinogenic tumours of the testis and in the evaluation of effectiveness of their treatment. Int J Cancer 11:586-594

Famulski W, Sulkowska M, Wincewicz A, Kedra B, Pawlak K, Zalewski B, Sulkowski S, Koda M, Baltaziak M (2006) P53 correlates positively with VEGF in preoperative sera of colorectal cancer patients. Neoplasma 53:43-48

Francí C, Takkunen M, Dave N, Alameda F, Gómez S, Rodríguez R, Escrivà M, Montserrat-Sentís B, Baró T, Garrido M, Bonilla $\mathrm{F}$, Virtanen I, García de Herreros A (2006) Expression of Snail protein in tumor-stroma interface. Oncogene 25:5134-5144

Fritah A, Saucier C, De Wever O, Bracke M, Bièche I, Lidereau R, Gespach C, Drouot S, Redeuilh G, Sabbah M (2008) Role of WISP-2/CCN5 in the maintenance of a differentiated and noninvasive phenotype in human breast cancer cells. Mol Cell Biol 28:1114-1123

Fuchs BC, Fujii T, Dorfman JD, Goodwin JM, Zhu AX, Lanuti M, Tanabe KK (2008) Epithelial-to-mesenchymal transition and integrin-linked kinase mediate sensitivity to epidermal growth factor receptor inhibition in human hepatoma cells. Cancer Res 68:2391-2399

Gadducci A, Ferdeghini M, Cosio S, Annicchiarico C, Ciampi B, Bianchi R, Genazzani AR (1999) Preoperative serum E-cadherin assay in patients with ovarian carcinoma. Anticancer Res 19:769-772

Gadducci A, Cosio S, Carpi A, Nicolini A, Genazzani AR (2004) Serum tumor markers in the management of ovarian, endometrial and cervical cancer. Biomed Pharmacother 58:24-38

Gazzaniga P, Nofroni I, Gandini O, Silvestri I, Frati L, Aglianò AM, Gradilone A (2005) Tenascin C and epidermal growth factor receptor as markers of circulating tumoral cells in bladder and colon cancer. Oncol Rep 14:1199-1202

George ML, Tutton MG, Abulafi AM, Eccles SA, Swift RI (2002) Plasma basic fibroblast growth factor levels in colorectal cancer: a clinically useful assay? Clin Exp Metastasis 19:735-738

Gilles C, Polette M, Piette J, Birembaut P, Foidart J-M (1996) Epithelial-to-mesenchymal transition in HPV-33-transfected cervical keratinocytes is associated with increased invasiveness and expression of gelatinase A. Int J Cancer 59:661-666

Gleiberman AS, YuYu Sharovskaya, Chailakhjan LM (1989) 'Contact inhibition' of alpha-fetoprotein synthesis and junctional communication in adult mouse hepatocyte culture. Exp Cell Res $184: 228-234$

Goddard MJ, Wilson B, Grant JW (1991) Comparison of commercially available cytokeratin antibodies in normal and neoplastic adult epithelial and non-epithelial tissues. J Clin Pathol 44:660663

Granato AM, Nanni O, Falcini F, Folli S, Mosconi G, De Paola F, Medri L, Amadori D, Volpi A (2004) Basic fibroblast growth factor and vascular endothelial growth factor serum levels in breast cancer patients and healthy women: useful as diagnostic tools? Breast Cancer Res 6:R38-R45

Gregory PA, Bert AG, Paterson EL, Barry SC, Tsykin A, Farshid G, Vadas MA, Khew-Goodall Y, Goodall GJ (2008) The miR-200 family and miR-205 regulate epithelial to mesenchymal transition by targeting ZEB1 and SIP1. Nat Cell Biol 10:593-601

Gumus E, Erdamar S, Demirel G, Horasanli K, Kendirci M, Miroglu C (2004) Association of positive serum anti-p53 antibodies with poor prognosis in bladder cancer patients. Int J Urol 11:10701077

Guo A, Villén J, Kornhauser J, Lee KA, Stokes MP, Rikova K, Possemato A, Nardone J, Innocenti G, Wetzel R, Wang Y, MacNeill J, Mitchell J, Gygi SP, Rush J, Polakiewicz RD, Comb MJ (2008)
Signaling networks assembled by oncogenic EGFR and c-Met. Proc Natl Acad Sci USA 105:692-697

Hannigan G, Troussard AA, Dedhar S (2005) Integrin-linked kinase: a cancer therapeutic target unique among its ILK. Nat Rev Cancer 5:51-63

Hautmann S, Huland E, Grupp C, Haese A, Huland H (2000) Supersensitive prostate-specific antigen (PSA) in serum of women with benign breast disease or breast cancer. Anticancer Res 20:21512154

He L, Thomson JM, Hemann MT, Hernando-Monge E, Mu D, Goodson S, Powers S, Cordon-Cardo C, Lowe SW, Hannon GJ, Hammond SM (2005) A microRNA polycistron as a potential human oncogene. Nature 435:828-833

Hendrix MJC, Seftor EA, Seftor REB, Kasemeier-Kulesa J, Kulesa PM, Postovit L-M (2007) Reprogramming metastatic tumour cells with embryonic microenvironments. Nat Rev Cancer 7:246-255

Hilkens J, Bonfrer JM, Kroezen V, van Eykeren M, Nooyen W, de Jong-Bakker M, Bruning PF (1987) Comparison of circulating MAM-6 and CEA levels and correlation with the estrogen receptor in patients with breast cancer. Int J Cancer 39:431-435

Hlubek F, Brabletz T, Budczies J, Pfeiffer S, Jung A, Kirchner T (2007) Heterogeneous expression of Wnt/B-catenin target genes within colorectal cancer. Int J Cancer 121:1941-1948

Homer JJ, Greenman J, Stafford ND (2002) Circulating angiogenic cytokines as tumour markers and prognostic factors in head and neck squamous cell carcinoma. Clin Otolaryngol Allied Sci 27:32-37

Huang Y, Fernandez SV, Goodwin S, Russo PA, Russo IH, Sutter TR, Russo J (2007) Epithelial to mesenchymal transition in human breast epithelial cells transformed by 173 -estradiol. Cancer Res 67:11147-11157

Hugo H, Ackland ML, Blick T, Lawrence MG, Clements JA, Williams ED, Thompson EW (2007) Epithelial-mesenchymal and mesenchymal-epithelial transitions in carcinoma progression. J Cell Physiol 213:374-383

Ishiwata T, Takahashi K, Shimanuki Y, Ohashi R, Cui R, Takahashi F, Shimizu K, Miura K, Fukuchi Y (2005) Serum tenascin-C as a potential predictive marker of angiogenesis in non-small cell lung cancer. Anticancer Res 25:489-495

Johnson CD, Esquela-Kerscher A, Stefani G, Byrom M, Kelnar K, Ovcharenko D, Wilson M, Wang X, Shelton J, Shingara J, Chin L, Brown D, Slack FJ (2007) The let-7 microRNA represses cell proliferation pathways in human cells. Cancer Res 67:7713-7722

Jung J-W, Hwang S-Y, Hwang J-S, Oh E-S, Park S, Han I-O (2007) Ionising radiation induces changes associated with epithelialmesenchymal transdifferentiation and increased cell motility of A549 lung epithelial cells. Eur J Cancer 43:1214-1224

Kalluri R, Neilson EG (2003) Epithelial-mesenchymal transition and its implications for fibrosis. J Clin Invest 112:1776-1784

Kawano T, Yanoma S, Nakamura Y, Shiono O, Kokatu T, Kubota A, Furukawa M, Tsukuda M (2005) Evaluation of soluble adhesion molecules CD44 (CD44st, CD44v5, CD44v6), ICAM-1, and VCAM-1 as tumor markers in head and neck cancer. Am J Otolaryngol 26:308-313

Kolomecki K, Maciaszczyk P, Stepien H, Stepien T, Kuzdak K, Ulanska J (2005) P53 concentration and soluble FasL (sFasL) serum level as indicators of apoptosis in patients with benign and malignant thyroid tumors. Bratisl Lek Listy 106:297-300

Kuefer R, Hofer MD, Zorn CSM, Engel O, Volkmer BG, Juarez-Brito MA, Eggel M, Gschwend JE, Rubin MA, Day ML (2005) Assessment of a fragment of e-cadherin as a serum biomarker with predictive value for prostate cancer. Br J Cancer 92:2018-2023

Laurent-Puig P, Lubin R, Semhoun-Ducloux S, Pelletier G, Fourre C, Ducreux M, Briantais MJ, Buffet C, Soussi T (1995) Antibodies against $\mathrm{p} 53$ protein in serum of patients with benign or malignant pancreatic and biliary diseases. Gut 36:455-458 
Lawrence MG, Veveris-Lowe TL, Whitbread AK, Nicol DL, Clements JA (2007) Epithelial-mesenchymal transition in prostate cancer and the potential role of kallikrein serine proteases. Cells Tissues Organs 185:111-115

Le NH, Franken P, Fodde R (2008) Tumour-stroma interactions in colorectal cancer: converging on $\beta$-catenin activation and cancer stemness. Br J Cancer [Epub ahead of print]

Le Page C, Ouellet V, Madore J, Hudson TJ, Tonin PN, Provencher DM, Mes-Masson A-M (2006) From gene profiling to diagnostic markers: IL-18 and FGF-2 complement CA125 as serum-based markers in epithelial ovarian cancer. Int J Cancer 118:1750-1758

Lebret SC, Newgreen DF, Thompson EW, Ackland ML (2007) Induction of epithelial to mesenchymal transition in PMC42-LA human breast carcinoma cells by carcinoma-associated fibroblast secreted factors. Breast Cancer Res 9:R19

Lee JM, Dedhar S, Kalluri R, Thompson EW (2006) The epithelialmesenchymal transition: new insights in signaling, development, and disease. J Cell Biol 172:973-981

Lein M, Jung K, Weiss S, Schnorr D, Loening SA (1997) Soluble CD44 variants in the serum of patients with urological malignancies. Oncology 54:226-230

Lester RD, Jo M, Montel V, Takimoto S, Gonias SL (2007) uPAR induces epithelial-mesenchymal transition in hypoxic breast cancer cells. J Cell Biol 178:425-436

$\mathrm{Hz} \mathrm{Li,} \mathrm{Tb} \mathrm{Yi,} \mathrm{Zy} \mathrm{Wu} \mathrm{(2008)} \mathrm{Suspension} \mathrm{culture} \mathrm{combined} \mathrm{with} \mathrm{che-}$ motherapeutic agents for sorting of breast cancer stem cells. BMC Cancer 8:135

Luo JC, Zehab R, Anttila S, Ridanpaa M, Husgafvel-Pursiainen K, Vainio H, Carney W, De Vivo I, Milling C, Brandt-Rauf PW (1994) Detection of serum p53 protein in lung cancer patients. J Occup Med 36:155-160

Mani SA, Yang J, Brooks M, Schwaninger G, Zhou A, Miura N, Kutok JL, Hartwell K, Richardson AL, Weinberg RA (2007) Mesenchyme Forkhead 1 (FOXC2) plays a key role in metastasis and is associated with aggressive basal-like breast cancers. Proc Natl Acad Sci USA 104:10069-10074

Mariotti A, Perotti A, Sessa C, Rüegg C (2007) N-cadherin as a therapeutic target in cancer. Expert Opin Investig Drugs 16:451-465

Martin TA, Goyal A, Watkins G, Jiang WG (2005) Expression of the transcription factors snail, slug, and twist and their clinical significance in human breast cancer. Ann Surg Oncol 12:488-496

McIntire KR, Waldmann TA, Moertel CG, Go VLW (1975) Serum $\alpha$-fetoprotein in patients with neoplasms of the gastrointestinal tract. Cancer Res 35:991-996

McMeekin DS, Sill MW, Darcy KM, Stearns-Kurosawa DJ, Webster K, Waggoner S, Benbrook D (2007) A phase II trial of thalidomide in patients with refractory leiomyosarcoma of the uterus and correlation with biomarkers of angiogenesis: a gynecologic oncology group study. Gynecol Oncol 106:596-603

Meyer GE, Yu E, Siegal JA, Petteway JC, Blumenstein BA, Brawer MK (1995) Serum basic fibroblast growth factor in men with and without prostate carcinoma. Cancer 76:2304-2311

Mihaylova Zh, Ludovini V, Gregorg V, Floriani I, Pistola L, Toffaneti F, Ferraldeschi M, Spreafico A, Ceresoli GL, Bellet M, Darwish S, Tonato M, Raynov J (2007) Serum level changes of matrix metalloproteinases 2 and 9, vascular endothelial growth factor and epidermal growth factor receptor during platinum-based chemotherapy in advanced non-small cell lung cancer patients. J BUON 12:105-111

Molina R, Santabarbara P, Filella X, Mengual P, Ballesta AM, Balague A (1989) Relationship of CA 125 and CA 19.9 with lung carcinoma histological subtype: preliminary study. Int J Biol Markers 4:215-220

Moody SE, Perez D, T-c Pan, Sarkisian CJ, Portocarrero CP, Sterner CJ, Notorfrancesco KL, Cardiff RD, Chodosh LA (2005) The transcriptional repressor Snail promotes mammary tumor recurrence. Cancer Cell 8:197-209

Müller M, Meyer M, Schilling T, Ulsperger E, Lehnert T, Zentgraf H, Stremmel W, Volkmann M, Galle PR (2006) Testing for anti-p53 antibodies increases the diagnostic sensitivity of conventional tumor markers. Int J Oncol 29:973-980

Murray PV, Soussi T, O’Brien MER, Smith IE, Brossault S, Norton A, Ashley S, Tavassoli M (2000) Serum p53 antibodies: predictors of survival in small-cell lung cancer? Br J Cancer 83:1418-1424

Nguyen Q-D, De Wever O, Bruyneel E, Hendrix A, Xie W-Z, Lombet A, Leibl M, Mareel M, Gieseler F, Bracke M, Gespach C (2005) Commutators of PAR-1 signaling in cancer cell invasion reveal an essential role of the Rho-Rho kinase axis and tumor microenvironment. Oncogene 24:8240-8251

Nieto MA (2002) The Snail superfamily of zinc-finger transcription factors. Nat Rev Mol Cell Biol 3:155-166

Nutt JE, Durkan GC, Mellon JK, Lunec J (2003) Matrix metalloproteinases (MMPs) in bladder cancer: the induction of MMP9 by epidermal growth factor and its detection in urine. BJU Int 91:99104

Obiezu CV, Diamandis EP (2005) Human tissue kallikrein gene family: applications in cancer. Cancer Lett 224:1-22

Papantoniou V, Tsiouris S, Koutsikos J, Ptohis N, Lazaris D, Zerva C (2006) Increased serum carbohydrate antigen 19-9 in relapsed ductal breast carcinoma. Hell J Nucl Med 9:36-38

Parikh B, Trivedi P, Shukla K (2007) A unilateral teratoid Wilms' tumor with raised serum alpha-fetoprotein level. Indian J Pathol Microbiol 50:317-319

Park S-M, Gaur AB, Lengyel E, Peter ME (2008) The miR-200 family determines the epithelial phenotype of cancer cells by targeting the E-cadherin repressors ZEB1 and ZEB2. Genes Dev 22:894907

Paszek MJ, Zahir N, Johnson KR, Lakins JN, Rozenberg GI, Gefen A, Reinhart-King CA, Margulies SS, Dembo M, Boettiger D, Hammer DA, Weaver VM (2005) Tensional homeostasis and the malignant phenotype. Cancer Cell 8:241-254

Patel BP, Shah SV, Shukla SN, Shah PM, Patel PS (2007) Clinical significance of MMP-2 and MMP-9 in patients with oral cancer. Head Neck 29:564-572

Pauli C, Stieber P, Schmitt UM, Andratschke M, Hoffmann K, Wollenberg B (2002) The significance of Tenascin-C serum level as tumor marker in squamous cell carcinoma of the head and neck. Anticancer Res 22:3093-3097

Peinado H, Olmeda D, Cano A (2007) Snail, Zeb and bHLH factors in tumour progression: an alliance against the epithelial phenotype? Nat Rev Cancer 7:415-428

Polascik TJ, Oesterling JE, Partin AW (1999) Prostate specific antigen: a decade of discovery - what we have learned and where we are going. J Urol 162:293-306

Ren Y, Cao B, Law S, Xie Y, Lee PY, Cheung L, Chen Y, Huang X, Chan HM, Zhao P, Luk J, Vande Woude G, Wong J (2005) Hepatocyte growth factor promotes cancer cell migration and angiogenic factors expression: a prognostic marker of human esophageal squamous cell carcinomas. Clin Cancer Res 11:6190 6197

Ritts RE Jr, Del Villano BC, Go VL, Herberman RB, Klug TL, Zurawski VR Jr (1984) Initial clinical evaluation of an immunoradiometric assay for CA 19-9 using the NCI serum bank. Int J Cancer 33:339-345

Rosen EM, Joseph A, Jin L, Yao Y, Chau M-HT, Fuchs A, Gomella L, Hastings H, Goldberg ID, Weiss GH (1997) Urinary and tissue levels of scatter factor in transitional cell carcinoma of bladder. J Urol 157:72-78

Rosivatz E, Becker I, Specht K, Fricke E, Luber B, Busch R, Höfler H, Becker K-F (2002) Differential expression of the epithelial- 
mesenchymal transition regulators Snail, SIP1, and Twist in gastric cancer. Am J Pathol 161:1881-1891

Sabbah M, Emami S, Redeuilh G, Zimber A, Bracke M, De Wever O, Gespach C (2008) Molecular signatures and clinical significance of the epithelial-mesenchymal transitions in human epithelial cancers. Drug Resist Updat (in press)

Sahlgren C, Gustafsson MV, Jin S, Poellinger L, Lendahl U (2008) Notch signaling mediates hypoxia-induced tumor cell migration and invasion. Proc Natl Acad Sci USA 105:6392-6397

Saito H, Tsujitani S, Katano K, Ikeguchi M, Maeta M, Kaibara N (1998) Serum concentration of CD44 variant 6 and its relation to prognosis in patients with gastric carcinoma. Cancer 83:10941101

Sarrió D, Rodriguez-Pinilla SM, Hardisson D, Cano A, Moreno-Bueno G, Palacios J (2008) Epithelial-mesenchymal transition in breast cancer relates to the basal-like phenotype. Cancer Res 68:989997

Segawa Y, Takigawa N, Mandai K, Maeda Y, Takata I, Fujimoto N, Jinno K (1997) Measurement of serum p53 protein in patients with small cell lung cancer and results of its clinicopathological evaluation. Lung Cancer 16:229-238

Semb H, Christofori G (1998) The tumor-suppressor function of E-cadherin. Am J Hum Genet 63:1588-1593

Shariat SF, Matsumoto K, Casella R, Jian W, Lerner SP (2005) Urinary levels of soluble E-cadherin in the detection of transitional cell carcinoma of the urinary bladder. Eur Urol 48:69-76

Sheen-Chen S-M, Liu Y-W, Eng H-L, Chou F-F (2005) Serum levels of hepatocyte growth factor in patients with breast cancer. Cancer Epidemiol Biomarkers Prev 14:715-717

Sliutz G, Tempfer C, Obermair A, Reinthaller A, Gitsch G, Kainz C (1995) Serum evaluation of basic fibroblast growth factor in cervical cancer patients. Cancer Lett 94:227-231

Somiari SB, Somiari RI, Heckman CM, Olsen CH, Jordan RM, Russell SJ, Shriver CD (2006) Circulating MMP2 and MMP9 in breast cancer-potential role in classification of patients into low risk, high risk, benign disease and breast cancer categories. Int J Cancer 119:1403-1411

Spaderna S, Schmalhofer O, Hlubek F, Berx G, Eger A, Merkel S, Jung A, Kirchner T, Brabletz T (2006) A transient, EMT-linked loss of basement membranes indicates metastasis and poor survival in colorectal cancer. Gastroenterology 131:830-840

Spaderna S, Schmalhofer O, Wahlbuhl M, Dimmler A, Bauer K, Sul$\tan$ A, Hlubek F, Jung A, Strand D, Eger A, Kirchner T, Behrens J, Brabletz T (2008) The transcriptional repressor ZEB1 promotes metastasis and loss of cell polarity in cancer. Cancer Res 68:537544

Stemmer V, de Craene B, Berx G, Behrens J (2008) Snail promotes Wnt target gene expression and interacts with B-catenin. Oncogene [Epub ahead of print]

Stickeler E, Vogl FD, Denkinger T, Mobus VJ, Kreienberg R, Runnebaum IB (2000) Soluble CD44 splice variants and pelvic lymph node metastasis in ovarian cancer patients. Int J Mol Med 6:595601

Strumane K, Berx G, Van Roy F (2004) Cadherins in cancer. In: Behrens J, Nelson NW (eds) Cell adhesion, series: handbook of experimental pharmacology, vol 165. Springer, Berlin, pp 69-103

Suwa H, Ohshio G, Okada N, Wang Z, Fukumoto M, Imamura T, Imamura $M$ (1997) Clinical significance of serum p53 antigen in patients with pancreatic carcinomas. Gut 40:647-653

Suzuki H, Akakura K, Igarashi T, Ueda T, Ito H, Watanabe M, Nomura F, Ochiai T, Shimada H (2004) Clinical usefulness of serum antip53 antibodies for prostate cancer detection: a comparative study with prostate specific antigen parameters. J Urol 171:182186

Symowicz J, Adley BP, Gleason KJ, Johnson JJ, Ghosh S, Fishman DA, Hudson LG, Stack MS (2007) Engagement of collagen-bind- ing integrins promotes matrix metalloproteinase-9-dependent Ecadherin ectodomain shedding in ovarian carcinoma cells. Cancer Res 67:2030-2039

Takamizawa J, Konishi H, Yanagisawa K, Tomida S, Osada H, Endoh H, Harano T, Yatabe Y, Nagino M, Nimura Y, Mitsudomi T, Takahashi T (2004) Reduced expression of the let-7 microRNAs in human lung cancers in association with shortened postoperative survival. Cancer Res 64:3753-3756

Takeda A, Otani Y, Iseki H, Takeuchi H, Aikawa K, Tabuchi S, Shinozuka N, Saeki T, Okazaki Y, Koyama I (2007) Clinical significance of large tenascin-C spliced variant as a potential biomarker for colorectal cancer. World J Surg 31:388-394

Takigawa N, Segawa Y, Maeda Y, Takata I, Fujimoto N (1997) Serum hepatocyte growth factor/scatter factor levels in small cell lung cancer patients. Lung Cancer 17:211-218

Tanaka K, Miki C, Wakuda R, Kobayashi M, Tonouchi H, Kusunoki M (2004) Circulating level of hepatocyte growth factor as a useful tumor marker in patients with early-stage gastric carcinoma. Scand J Gastroenterol 39:754-760

Tang R, Ko M-C, Wang J-Y, Changchien CR, Chen HH, Chen J-S, Hsu K-C, Chiang J-M, Hsieh L-L (2001) Humoral response to p53 in human colorectal tumors: a prospective study of 1, 209 patients. Int J Cancer 94:859-863

Tarin D, Thompson EW, Newgreen DF (2005) The fallacy of epithelial mesenchymal transition in neoplasia. Cancer Res 65:5996-6001

Thiery JP, Sleeman JP (2006) Complex networks orchestrate epithelial-mesenchymal transitions. Nat Rev Mol Cell Biol 7:131-142

Thomas PA, Kirschmann DA, Cerhan JR, Folberg R, Seftor EA, Sellers TA, Hendrix MJC (1999) Association between keratin and vimentin expression, malignant phenotype, and survival in postmenopausal breast cancer patients. Clin Cancer Res 5:2698-2703

Thomson DMP, Krupey J, Freedman SO, Gold P (1969) The radioimmunoassay of circulating carcinoembryonic antigen of the human digestive system. Proc Natl Acad Sci USA 64:161-167

Thomson S, Buck E, Petti F, Griffin G, Brown E, Ramnarine N, Iwata KK, Gibson N, Haley JD (2005) Epithelial to mesenchymal transition is a determinant of sensitivity of non-small-cell lung carcinoma cell lines and xenografts to epidermal growth factor receptor inhibition. Cancer Res 65:9455-9462

Thuault S, Valcourt U, Petersen M, Manfioletti G, Heldin C-H, Moustakas A (2006) Transforming growth factor- $\beta$ employs HMGA2 to elicit epithelial-mesenchymal transition. J Cell Biol 174:175-183

Trimboli AJ, Fukino K, de Bruin A, Wei G, Shen L, Tanner SM, Creasap N, Rosol TJ, Robinson ML, Eng C, Ostrowski MC, Leone G (2008) Direct evidence for epithelial-mesenchymal transitions in breast cancer. Cancer Res 68:937-945

Ueno K, Inoue Y, Kawaguchi T, Hosoe S, Kawahara M (2001) Increased serum levels of basic fibroblast growth factor in lung cancer patients: relevance to response of therapy and prognosis. Lung Cancer 31:213-219

Usami Y, Satake S, Nakayama F, Matsumoto M, Ohnuma K, Komori T, Semba S, Ito A, Yokozaki H (2008) Snail-associated epithelialmesenchymal transition promotes oesophageal squamous cell carcinoma motility and progression. J Pathol 215:330-339

Van Aken E, De Wever O, Correia da Rocha AS, Mareel M (2001) Defective E-cadherin/catenin complexes in human cancer. Virchows Arch 439:725-751

Van de Putte T, Maruhashi M, Francis A, Nelles L, Kondoh H, Huylebroeck D, Higashi Y (2003) Mice lacking ZFHX1B, the gene that codes for Smad-interacting protein-1, reveal a role for multiple neural crest cell defects in the etiology of Hirschsprung disease-mental retardation syndrome. Am J Hum Genet 72:465-470

Van Marck VL, Bracke ME (2005) Epithelial-mesenchymal transitions in human cancer. In: Savagner P (ed) Rise and fall of epithelial phenotype. Concepts of epithelial-mesenchymal transition, Chapter 9. Landes Bioscience, Georgetown, pp 135-159 
Vandewalle C, Comijn J, De Craene B, Vermassen P, Bruyneel E, Andersen H, Tulchinsky E, Van Roy F, Berx G (2005) SIP1/ ZEB2 induces EMT by repressing genes of different epithelial cell-cell junctions. Nucleic Acids Res 33:6566-6578

Vasko V, Espinosa AV, Scouten W, He H, Auer H, Liyanarachchi S, Larin A, Savchenko V, Francis GL, de la Chapelle A, Saji M, Ringel MD (2007) Gene expression and functional evidence of epithelial-to-mesenchymal transition in papillary thyroid carcinoma invasion. Proc Natl Acad Sci USA 104:2803-2808

Velikova G, Banks RE, Gearing A, Hemingway I, Forbes MA, Preston SR, Hall NR, Jones M, Wyatt J, Miller K, Ward U, Al-Maskatti J, Singh SM, Finan PJ, Ambrose NS, Primrose JN, Selby PJ (1998) Serum concentrations of soluble adhesion molecules in patients with colorectal cancer. Br J Cancer 77:1857-1863

Venkov CD, Link AJ, Jennings JL, Plieth D, Inoue T, Nagai K, Xu C, Dimitrova YN, Rauscher FJIII, Neilson EG (2007) A proximal activator of transcription in epithelial-mesenchymal transition. J Clin Invest 117:482-491

Verona EV, Elkahloun AG, Yang J, Bandyopadhyay A, Yeh I-T, Sun L-Z (2007) Transforming growth factor- $\beta$ signaling in prostate stromal cells supports prostate carcinoma growth by up-regulating stromal genes related to tissue remodeling. Cancer Res 67:5737-5746

Vesely D, Astl J, Lastuvka P, Matucha P, Sterzl I, Betka J (2004) Serum levels of IGF-I, HGF, TGFß1, bFGF and VEGF in thyroid gland tumors. Physiol Res 53:83-89

Vignjevic D, Schoumacher M, Gavert N, Janssen K-P, Jih G, Laé M, Louvard D, Ben-Ze'ev A, Robine S (2007) Fascin, a novel target of B-catenin-TCF signaling, is expressed at the invasive front of human colon cancer. Cancer Res 67:6844-6853

Voorhoeve PM, le Sage C, Schrier M, Gillis AJM, Stoop H, Nagel R, Liu Y-P, van Duijse J, Drost J, Griekspoor A, Zlotorynski E, Yabuta N, De Vita G, Nojima H, Looijenga LHJ, Agami R (2006) A genetic screen implicates miRNA-372 and miRNA-373 as oncogenes in testicular germ cell tumors. Cell 124:1169-1181

Wang X, Zheng M, Liu G, Xia W, McKeown-Longo PJ, Hung MC, Zhao J (2007) Krüppel-like factor 8 induces epithelial to mesenchymal transition and epithelial cell invasion. Cancer Res 67:7184-7193

Wheelock MJ, Shintani Y, Maeda M, Fukumoto Y, Johnson KR (2008) Cadherin switching. J Cell Sci 121:727-735
Wild-Bode C, Weller M, Rimner A, Dichgans J, Wick W (2001) Sublethal irradiation promotes migration and invasiveness of glioma cells: implications for radiotherapy of human glioblastoma. Cancer Res 61:2744-2750

Wu X, Chen H, Parker B, Rubin E, Zhu T, Lee JS, Argani P, Sukumar $\mathrm{S}$ (2006) HOXB7, a homeodomain protein, is overexpressed in breast cancer and confers epithelial-mesenchymal transition. Cancer Res 66:9527-9534

Yager JD, Davidson NE (2006) Estrogen carcinogenesis in breast cancer. N Engl J Med 354:270-282

Yanaihara N, Caplen N, Bowman E, Seike M, Kumamoto K, Yi M, Stephens RM, Okamoto A, Yokota J, Tanaka T, Calin GA, Liu CG, Croce CM, Harris CC (2006) Unique microRNA molecular profiles in lung cancer diagnosis and prognosis. Cancer Cell 9:189-198

Yang J, Mani SA, Donaher JL, Ramaswamy S, Itzykson RA, Come C, Savagner P, Gitelman I, Richardson A, Weinberg RA (2004) Twist, a master regulator of morphogenesis, plays an essential role in tumor metastasis. Cell 117:927-939

Yang AD, Fan F, Camp ER, van Buren G, Liu W, Somcio R, Gray MJ, Cheng H, Hoff PM, Ellis LM (2006) Chronic oxaliplatin resistance induces epithelial-to-mesenchymal transition in colorectal cancer cell lines. Clin Cancer Res 12:4147-4153

Yang M-H, Wu M-Z, Chiou S-H, Chen P-M, Chang S-Y, Liu C-J, Teng S-C, Wu K-J (2008) Direct regulation of TWIST by HIF- $1 \alpha$ promotes metastasis. Nat Cell Biol 10:295-305

Yauch RL, Januario T, Eberhard DA, Cavet G, Zhu W, Fu L, Pham TQ, Soriano R, Stinson J, Seshagiri S, Modrusan Z, Lin C-Y, O’Neill V, Amler LC (2005) Epithelial versus mesenchymal phenotype determines in vitro sensitivity and predicts clinical activity of erlotinib in lung cancer patients. Clin Cancer Res 11:86868698

Zhang B, Groffen J, Heisterkamp N (2007) Increased resistance to a farnesyltransferase inhibitor by $\mathrm{N}$-cadherin expression in $\mathrm{Bcr} /$ Abl-P190 lymphoblastic leukemia cells. Leukemia 21:1189 1197

Zhu C-Q, Popova SN, Brown ERS, Barsyte-Lovejoy D, Navab R, Shih W, Li M, Lu M, Jurisica I, Penn LZ, Gullberg D, Tsao M-S (2007) Integrin $\alpha 11$ regulates IGF2 expression in fibroblasts to enhance tumorigenicity of human non-small-cell lung cancer cells. Proc Natl Acad Sci USA 104:11754-11759 